\title{
Effect of defoliation by Thaumetopoea pityocampa (Den. \& Schiff.) (Lepidoptera: Thaumetopoeidae) on annual diameter increment of Pinus brutia Ten. in Turkey
}

\author{
Mehmet KANAT $^{\mathrm{a} *}$, M. Hakki AlMA ${ }^{\mathrm{b} *}$, Fatih SIVRIKAYA ${ }^{\mathrm{a}}$ \\ a Department of Forest Engineering, Faculty of Forestry, Kahramanmaras Sutcu Imam University, 46060 Kahramanmaras, Turkey \\ b Department of Industrial Engineering of Forestry, Faculty of Forestry, Kahramanmaras Sutcu Imam University, 46060 Kahramanmaras, Turkey
}

(Received 13 October 2003; accepted 24 May 2004)

\begin{abstract}
In this study, the influence of defoliation by pine processionary moth, Thaumetopoea pityocampa (Den. \& Schiff.) (Lepidoptera: Thaumetopoeidae) on the annual diameter increment of Turkish Calabrian pine, Pinus brutia Ten. in Kahramanmaras province, Turkey, was investigated. The study was carried out between 1995 and 1998. During the four years, the defoliation of pine processionary moth caused a significant decrease (average $21 \%$ for four years, $P<0.05$ ) in the annual diameter increment with respect to control, undefoliated trees.
\end{abstract}

Thaumetopoea pityocampa / diameter increment / Kahramanmaras / Turkey / Pinus brutia

Résumé - Effet des défeuillaisons par Thaumetopoea pityocampa (Den. \& Schiff.) sur l'accroissement annuel de Pinus brutia Ten. en Turquie. L'influence de défeuillaisons par la processionnaire du Pin Thaumetopoea pityocampa, sur l'accroissement annuel en diamètre de Pinus brutia, a été testée dans la province de Kahramanmaras, en Turquie. L'étude fut conduite de 1995 à 1998 . Durant ces 4 années, les défeuillaisons ont causé une diminution significative (en moyenne $21 \%$ pour les 4 ans, $P<0,05$ ) de l'accroissement annuel en diamètre, en comparaison avec des témoins non défeuillés.

Thaumetopoea pityocampa / accroissement en diamètre / Kahramanmaras / Turquie / Pinus brutia

\section{INTRODUCTION}

The pine processionary moth (PPM) live on the genera Pinus and Cedrus grown in Cyprus, Turkey and Middle East and has been known as Thaumetopoea pityocampa (Den. \& Schiff.) until now, except for the population found in the province of Aydn, Aegean region of Turkey [27]. However, there is the possibility that the species studied in this paper may refer to Th. wilkinsoni Tams known from Cyprus, Eastern Turkey, and Israel [27]. Further studies are needed to clarify the taxonomic position of the studied populations.

Th. pityocampa Schiff is known to feed on leaves and build large silk nests on the top of the trees. In addition, PPM has urticating hairs, which cause allergies resulting in conjunctivitis, respiratory congestions and asthma [29]. The PPM is one of the most harmful insect that defoliates Pinus and Cedrus and has serious economic importance $[2,4,5,8,16,20-24,26,28]$. In mature forests, trees are barely killed, but significant losses bring about in volume and radial growths [18].
It is well known that defoliation may increase tree stress and their susceptibility to secondary pests such as bark beetles and pine weevils, particularly in young trees $[11,15,16]$. Outbreaks of PPM are quite periodic, occurring every 5-7 years. It was also reported that losses in total shoots of $P$. pinaster were between $41-50 \%$ in moderately defoliated trees and between 54-64\% in completely defoliated trees [25]. Due to PPM attack on Pinus brutia (with 1-4 m height) in Turkey, a great loss of $68 \%$ was determined by Babur [5].

PPM has been damaging pine species (i.e., Pinus brutia, $P$. nigra, $P$. sylvestris, $P$. pinea, and $P$. halepensis) as well as species Cedrus libani growing in Turkey. The PPM occurs at the regions from sea level to an altitude of 1800 meters [3,12] at different levels of intensity. In Turkey, the PPM is available in a forest area of 1500000 hectares [1].

The damage of PPM has been mostly observed on P. brutia in Turkey, which consists of the majority of forests (with more than 3 million hectares) and are distributed particularly in the coastal regions of Turkey, namely, the Mediterranean (47\%),

* Corresponding authors: mkanat@ksu.edu.tr, alma@ksu.edu.tr 
Marmara regions (40\%) and Aegean (10\%) [1, 12]. It has a volume of more than 161 million $\mathrm{m}^{3}$ and an annual volume increment of more than 5 million $\mathrm{m}^{3}, 4$ million $\mathrm{m}^{3}$ of which is allowed to be cut [6]. The PPM created severe damage in an area of about 1.5 million hectares in Turkey [1]. It was reported that the damage resulted from larvae being nourished with the needles of $P$. brutia and $P$. nigra continued for about 7 or 8 months to a great extent. Especially, the larvae at the 4th and 5 th instars consume all the leaves of the Calabrian pine trees remarkably. Thereby, the damaged trees look like as if they were burned [17].

There are several studies on the effects of the attacks of $T h$. pityocampa (Den. \& Schiff.) on the radial [5, 18, 19], volume $[7,9]$ and the height growths [10] of various pine species. To our knowledge, little information $[5,16]$ on the effects of the PPM attack on annual diameter increment of $P$. brutia has been known in the literature so far.

Therefore, the aim of this study was to investigate the influence of damage by the PPM on annual diameter increment of $P$. brutia growing in Kahramanmaras, the Eastern Mediterranean region of Turkey.

\section{MATERIALS AND METHODS}

\subsection{Selection of material and study area}

The study area of both control and defoliated trees was around Ferhus village (with plantation forest), within the boundaries of the Directorate of Kahramanmaras Forest District, Turkey (322 500 E; 4155000 N (UTM grit zone $37 \mathrm{~S}$ ); altitude $560 \mathrm{~m}$ ).

Specifically, $P$. brutia forests in the region of Kahramanmaras cover an area of 192521 hectares, which corresponds to $6 \%$ of the total area of $P$. brutia forests in Turkey. About 87600 hectares (45\%) of the total area of $P$. brutia in Kahramanmaras region are unproductive while the remaining 104926 hectares $(55 \%)$ is productive [6, 14].

The diameter at the breast height of both control and defoliated pine trees (25-35 years old) studied herein varied between 13 and $19 \mathrm{~cm}$. Undefoliated trees and trees whose about two-thirds of needles of $P$. brutia (i.e., especially from the top to middle of tree) were estimated to have been defoliated by PPM were selected for control and defoliated trees, respectively. The control trees were managed to keep free of attack throughout by removing the egg batches on trees in September and October. Furthermore, the average height of both control and defoliated trees in this study ranged between 11-12 $\mathrm{m}$. The exposure of the study area for both control and defoliated trees were north-east.

\subsection{Observation on the PPM defoliation}

The feeding of larvae was found to take place much more in April and May rather than other months in the study area. And then, trees foliated themselves, starting from May to July. In the study area, the first natural outbreak was observed in 1994, followed by 1995 (78 nests on each defoliated tree), 1996 (5-6 nests), 1997 (6-7 nests) and 1998 (3-4 nests). It was also observed that PPM laid about 273 eggs in one egg batch on the needles of P. brutia trees in September, 1995. Generally speaking, two-thirds of needles of $P$. brutia (i.e., especially from the top to middle of tree) were estimated to have been defoliated by the larvae in these infestation years. About $24 \%$ of these eggs were destroyed due to pressure of some parasitoids and environmental factors. And then, the number of larvae hatched in September-October is 208 in each egg batch.
In the study area, the larvae generally entered the soil for pupae in May, and pupae could live for 4 years in the soil. Between the years 1995 and 1998, the population of PPM remained at a certain level. In addition, it was observed that in the years at which infestation decreased, the population of Calosoma sycophanta and Phryxe caudata considerably increased.

\subsection{Determination of annual diameter increment}

The measurements of the diameter at the breast height of $P$. brutia trees were obtained using a Pressler increment bore (Djos 400, diameter: $6 \mathrm{~mm}$, height: $33 \mathrm{~cm}$, made in Sweden) and a Zeiss Winkel apparatus (Dendromotor 2000, made in Finland). Annual diameter increment $(A D I)$ and percent decrease in annual diameter increment (PDADI) were determined as follows:

$$
A D I=\left(D_{2}-D_{1}\right)(\mathrm{mm})
$$

where, $D_{2}$ is the diameter of the pine tree measured at the end of the vegetation period of each year and $D_{1}$ is the diameter of the tree measured at the beginning of vegetation period of each year.

$$
P D A D I=\left(A D I_{c}-A D I_{i}\right) / A D I_{c} \times 100(\%)
$$

where, $A D I_{i}$ is annual diameter increment for the pine trees defoliated by PPM and $A D I_{c}$ is annual diameter increment for the control pine trees.

Annual diameter (at the breast height) increments of the pine trees were measured for four different growing years, namely, 1995, 1996, 1997 and 1998. This study was conducted on the same trees throughout the studied years. For both the control and defoliated trees, the average of 30 measurements was reported.

The repeated measurement analysis of variance (rmANOVA) and Tukey's mean separation test were applied to determine whether or not there were significant differences in annual diameter increment of defoliated and control trees [13].

\section{RESULTS AND DISCUSSION}

The results of rmANOVA test for the annual diameter increment of both control and defoliated pine trees are presented in Table I. As shown in this table, the interaction of defoliation and growing years studied and year itself are not statistically significant. However, a strong significant difference is determined for defoliation, thus revealing that annual diameter increments in the pine trees are considerably affected by the defoliation of the larvae, $P<0.05$.

The results of Tukey's mean separation test for the diameter increment of the both control and defoliated trees as well as percent decrease in annual diameter increment are given in Table II. As indicated in this table, the annual diameter increments of the defoliated trees significantly differ from those of control trees for all the growing years at a significant level of $5 \%$. As one can see from the same table, there are no significant differences in the annual diameter increments of the defoliated trees between 1995 and 1998. However, the annual diameter increments determined in 1996 and 1997 are found to significantly differ from those in the other two years, 1995 and 1998, $P<0.05$.

Average decrease in annual diameter increment for four growing years is about $21 \%$. The greatest percent decrease (about 30\%) in the annual diameter increment of the pine trees 
Table I. The results of rmANOVA for annual diameter increment of control and defoliated Calabrian pine trees on the basis of times.

\begin{tabular}{|c|c|c|c|c|c|}
\hline Source & Sum of squares & DF & Mean square & $\mathrm{F}$ & Significance* \\
\hline Intercept & 1343.79 & 1 & 1343.79 & 555.40 & $* * *^{\mathrm{a}}$ \\
\hline Time & 78.55 & 1 & 78.55 & 32.47 & $* * *$ \\
\hline Defoliation & 14.60 & 3 & 4.86 & 15.17 & $* * *$ \\
\hline Error (within) & 55.76 & 174 & 0.32 & & \\
\hline Defoliation $\times$ time & 4.04 & 3 & 1.35 & 4.20 & $* * \mathrm{~b}$ \\
\hline Error (between) & 140.33 & 58 & 2.40 & & \\
\hline
\end{tabular}

${ }^{\mathrm{a}}$ Strong significant at the level of $5 \%(P<0.05) .{ }^{\mathrm{b}}$ Weak significance at the level of $5 \%(P<0.05)$.

Table II. The results of Tukey's mean separation test for the annual diameter increment of Calabrian pine trees (control and defoliated by PPM) on the basis of years.

\begin{tabular}{|c|c|c|c|}
\hline \multirow{2}{*}{ Years } & \multicolumn{2}{|c|}{ Mean annual diameter increment (mm) } & \multirow{2}{*}{ Percent decrease in annual diameter increment } \\
\hline & Control & Defoliation & \\
\hline 1995 & $2.36 \pm 0.30 \mathrm{a}^{*}$ & $1.64 \pm 0.10 \mathrm{~d}$ & 30 \\
\hline 1996 & $2.46 \pm 0.24 b$ & $2.02 \pm 0.16 \mathrm{e}$ & 18 \\
\hline 1997 & $2.33 \pm 0.21 \mathrm{a}$ & $1.85 \pm 0.13 \mathrm{f}$ & 20 \\
\hline 1998 & $1.93 \pm 0.19 c$ & $1.66 \pm 0.09 \mathrm{~d}$ & 14 \\
\hline
\end{tabular}

* Means followed by the same letter are not significantly different using Tukey's mean separation test (significance level is 0.05 ).

defoliated by the larvae is for the year of 1995 , followed by $20 \%$ in $1997,18 \%$ in 1996 and $14 \%$ in 1998, respectively (Tab. II).

This fact can be attributed to the number of nests on defoliated trees in relevant year based upon our observation described in material and method section. That is to say, the percent decrease in the annual diameter increment is found to be directly proportional to the nest number.

It was also reported that due to damage of PPM, an about $23 \%$-loss in annual diameter increment was measured in the tending felling area of $P$. brutia in Kapicam village, Kahramanmaras-Turkey, which is closed to the present study region [16].

Moreover, Laurent-Hervouet [18] found that the PPM caused a 35\%-loss in the diameter increment (radial growth) of $P$. nigra subsp. nigricans growing on Mont Ventoux after a severe attack of Th. pityocampa, which is slightly higher than the maximum loss $(30 \%)$ determined in this study. This may be attributed to both pine species and population of the PPM depending upon regions [1].

Cadahja and Insua [9] found out the losses in wood volume increment between 14 and $33 \%$ in young reforested area of $P$. radiata because of Th. pityocampa. Also, Bouchon and Toth [7] reported that forests of $P$. nigra periodically subjected to heavy attacks of Th. pityocampa showed an about $45 \%$-volume decrease within 50 years. This difference is due, most probably, to the age of tree and species $[10,16]$.

Lemoine [19] also determined a reduction of $30 \%$ in radial growth of $P$. pinaster in Les Landes (France) after an attack of Th. pityocampa and $20 \%$ loss in radial growth of $P$. nigra subsp. laricis in Corsica for the 28 years after the attack of the same moth. Decrease in the radial growth (about 21\%) determined for $P$. brutia, studied herein, attacked by the PPM was evidently smaller than that found for $P$. pinaster just mentioned above, and almost the same as that for P. nigra subsp. laricis grown in Corcica.

Furthermore, Calas [10] found a $60 \%$-reduction in height growth of $P$. nigra trees due to Th. pityocampa.

\section{REFERENCES}

[1] Anonymous, Harmful insects of forests, The Reports of the 5th Annual Development Plan, Turkey, 1995.

[2] Austra O., Orlund A.S., Weidahl A., Growth loss and economic consequences following two years of defoliation of Pinus sylvestris by the pine sawfly Neodiprion sertifer in West-Norway, Scand. J. For. Res. 2 (1987) 111-119.

[3] Avtzis N.D., The use of Bacillus thuringiensis against Thaumetopoea pityocampa Schiff. (Lepidoptera: Thaumetopoeidae) in Greece, USDA Forest Service General Technical Report, NE-247, 1998.

[4] Avtzis D.N., Control of the most dangerous insects of Greek forests and plantations, in: Liebhold A.M., Mcmanus M.L., Otvos I.S., Fosbroke S.L.C. (Eds.), Proceeding: Integrated management of forest defoliating insects, Victoria, BC, Gen. Tech. Rep. NE-277, 2001, pp. 1-5.

[5] Babur H., The effect of damage of Thaumetopoea pityocampa (Schiff.) in Calabrian pine seedling in Turkey, symposium on problems of Thaumetopoea pityocampa (Schiff.) in Turkey and their solutions (Kahramanmaras, Turkey), in: Kanat M. (Ed.), The Proceedings of Pine Processionary Moth Symposium (Kahramanmaras, Turkey), 2002, pp. 37-38 (with English abstract).

[6] Bektas I., Alma M.H., As N., Gundogan R., Relationship between site index and several mechanical properties of Turkish Calabrian pine (Pinus brutia Ten.), For. Prod. J. 53 (2003) 27-31.

[7] Bouchon J., Toth J., Étude préliminaire sur pertes de production des pinèdes soumises aux attaques de Thaumetopoea pityocampa Schiff., Ann. Sci. For. 28 (1971) 323-340. 
[8] Buxton R.D., Forest management and the pine processionary moth, Outlook on Agriculture 12 (1983) 34-39.

[9] Cadehia D., Insuan A., Estimation of the injury caused by Thaumetopoea pityocampa in Pinus radiata plantation, Bol. Serv. Plagas For. 13 (1970) 159-171.

[10] Calas J., La processionaire du pin, Revue Eaux et Forêts, 1897, pp. 705-723.

[11] Canakcioglu H., Forest entomology (special section), Istanbul University, Forestry Faculty publications, Istanbul, Turkey, 1993.

[12] Canakcioglu H., Mol T., Forest entomology, Istanbul University, Forestry Faculty publications, Istanbul, Turkey, 1998

[13] Efe E., Bek Y., Sahin M., Static methods II, University of Kahramanmaras Sutcu Imam publications, Kahramanmaras, Turkey, 2000.

[14] Göker Y., Technological properties of some growing trees, J. Istanbul Forestry Faculty 32 (1982) 24-30 (with English abstract).

[15] Kanat M., An Investigation on Harmful Insects in Kahramanmaras Forests, Ph.D. thesis, Karadeniz Technical University, Institute of Natural Science, Trabzon, Turkey, 1998.

[16] Kanat M., Sivrikaya F., Serez M., A research on damage of pine processionary moth (Thaumetopoea pityocampa Schiff.) on Pinus brutia Ten. Trees, and the effect of tending activities on the diameter increment of Calabran pine in Kahramanmaras, in: Kanat M. (Ed.), The Proceedings of Pine Processionary Moth Symposium, Kahramanmaras, Turkey, 2002, pp. 44-51 (with English abstract).

[17] Kanat M., Alma M.H., Insecticidal effects of essential oils from various plants against larvae of pine processionary moth (Thaumetopoea pityocampa Schiff.) (Lepidoptera: Thaumetopoeidae), Pest Manag. Sci. 60 (2) 173-177.

[18] Laurent-Hervouet N., Mesure des pertes de croissance radiale sur quelques espèces de Pinus dues à deux défoliateurs forestiers. I. Cas de la processionnaire du pin en région méditerranéenne, Ann. Sci. For. 43 (1986) 239-262.

[19] Lemoine B., Contribution à la mesure des pertes de production causées par la chenille processionaire Thaumetopoea pityocampa
Schiff au pin maritime dans les Landes de Gascogne, Ann. Sci. For. 34 (1977) 205-214.

[20] Lightle P.C., Weiss M.J., Dwarf misletoe of ponderosa pine in the Soutwest U.S., Departmant of Agriculture Forest Service, Forest insect \& Disease Leaflet 19 (1974) 1-7.

[21] Lyytikainen-saarenmaa P., Growth responses of Scots pine (Pinacae) to artificial and sawfly (Hymenoptera: Diprionidae) defoliation, Can. Entomol. 131 (1999) 455-463.

[22] Markalas S., Observations on the biology, the behavior and the damage caused by the pine processionary moth (Thaumetopoea pityocampa Schiff.), Aristotelian University of Thessalonici, Sc. Ann. Depart. For. Nat. Environ. 28 (1985) 303-370.

[23] Markalas S., Problems on the control of the pine processionary moth, Proceeding of the symposium Protection of Forests, Hellenic For. Soc., Athens, 1986, pp. 85-88.

[24] Markalas S., Influence of the attack by Thaumetopoea pityocampa Schiff. on the height increment of young pine tress, Aristotelian University of Thessalonici, Sc. Ann. Depart. For. Nat. Environ. 32 (1989) 177-195.

[25] Markalas S., Biomass production of Pinus pinaster after defoliation by the pine processionary moth (Thaumetopoea pityocampa Schiff.), USDA, For. Serv. Gen. Technical Report, NE-247, 1998.

[26] Rive J.L., Thaumetopoea pityocampa. Biology and control, Note, Inst. Rebois, Tunis, 1966.

[27] Salvato P., Battisti A., Concato S., Masutti L., Patarnello T., Zane L., Genetic differentiation in the winter pine processionary moth (Thaumetopoea pityocampa-wilkinsoni complex), inferred by AFLP and mitochondrial DNA markers, Mol. Ecol. 11 (2002) $2435-2444$

[28] Tiberi R., Niccoli A., Curini M., Epifano F., Marcotullio M.C., Rosati O., The role of the monoterpene in Pinus spp. needles, in host selection by the pine processionary moth, Thaumetopoed pityocampa, Phytoparasitica 27 (1999) 263-272.

[29] Ziprkowski L., Roland F., Study of the toxin from the poison hairs of Thaumetopoea wilkinsoni caterpillars, J. Invest. Dermatol. 46 (1966) 439-445. 